\title{
Aggression towards Referees in Amateur Football in Spain: A Loglinear Approach*
}

\section{Agresión hacia árbitros en partidos de fútbol amateur en España: una} aproximación log-lineal

Received: 11 November 2018 | Accepted: 17 January 2019

\author{
Diego Fuente \\ IES Número 26 Misericordia, Spain \\ ORCID: http://orcid.org/0000-0002-0951-1056 \\ ENRIQUe CANTÓN \\ Universitat de València, Spain \\ ORCID: http://orcid.org/0000-0001-6869-617X \\ Francisco Montes \\ Universitat de València, Spain \\ ORCID: http://orcid.org/0000-0002-1708-9385 \\ María Ángeles Sanruperto Abella \\ Generalitat Valenciana, Spain \\ ORCID: https://orcid.org/0000-0002-4810-2562
}

a Correspondence author. Email:

diego.fuente.fuente@gmail.com

How to cite: Fuente, D., Cantón, E., Montes, F., \& Sanruperto Abella, M. A. (2019). Aggression towards referees in amateur football in Spain: A loglinear approach. Universitas Psychologica, 18(3), 1-13. https://doi.org/10.11144/Javeriana.upsy18-3.araf

\begin{abstract}
Aggressive behavior towards football referees is becoming increasingly common, and as a result we are getting used to it and coming to see it as an inevitable and intrinsic element of football matches. Spectators, players and coaches are all prone to take this view. This article studies how the types of aggression shown by these three groups towards the referee are related to one another, and how they are perceived by the referee, in amateur football. For this purpose, the phenomenon was assessed, using an ad-hoc form, both by an expert and by the referee, in 119 regional and youth football matches in the city of Valencia and surrounding municipalities. We analysed the data using a loglinear model, which enabled us to establish that from the referee's perspective pairs of the above-mentioned groups influenced each other regardless of the attitude of the third group. On the other hand, departing from the traditional idea that aggressive behaviour by one of the groups determines the behaviour of the other two, the analysis of the expert's opinions on the attitudes of the three groups led us to a model in which their respective actions were independent of one another.

Keywords

Violence; referees; players; coaches; spectators; log linear models.
\end{abstract}

\section{RESUMEN}

El comportamiento agresivo hacia los árbitros de fútbol se está acrecentando de manera tal que como resultado estamos habituándonos a él y viéndolo como un elemento inevitable e intrínseco de los partidos de fútbol. Espectadores, jugadores y entrenadores son propensos a adoptar este punto de vista. Este artículo estudia cómo los tipos de agresión mostrados por estos tres grupos hacía el árbitro están relacionados los unos con los otros, y cómo son percibidos por el árbitro en fútbol 
amateur. Para cumplir este objetivo, el fenómeno fue evaluado utilizando un formato ad-hoc por un experto y por un árbitro, en 119 partidos de fútbol regionales y de jóvenes, en la ciudad de Valencia y municipalidades cercanas. Se analizaron los datos utilizando un modelo loglineal, que permite establecer que, desde la perspectiva de los árbitros, los grupos mencionados se influencian entre ellos sin importar la actitud del tercer grupo. Por otra parte, partiendo de la idea tradicional de que el comportamiento agresivo de uno de los grupos determina el de los otros dos, el análisis de la opinión de expertos acerca de las actitudes de los tres grupos lleva a un modelo en el que sus respectivas acciones son independientes. Palabras clave

violencia; árbitros; jugadores; entrenadores; espectadores; modelos log-lineales.

The number of incidents of aggression on referees reported in the media is increasing day by day, and they are increasingly accepted as normal. This is the starting point for the objective addressed in this study: to detect the real presence of such incidents in amateur football and observe the relationship between the different levels and types of aggression towards the referee originating from the main agents involved in a match. It involves studying the relationship or interaction that may exist between the aggression towards the referee shown by players, coaches and spectators, on the one hand, and on the other, of seeing whether the referee's perception of this aggression, formally recorded in the report after a match, exhibits some kind of relationship with that of these groups.

Although moral standards are quite clear, antisocial forms of behaviour are common in modern football, with clear examples such as cheating, verbal and even physical attacks (Kavussanu, 2006) and aggressive roles (Shields, Bredemeier, LaVoi, \& Power, 2005).

When the factors that trigger aggression in sport are reviewed, refereeing errors emerge as one of those factors, and in order to prevent such incidents, tools have been sought to foster fair play, as González-Oya (2010) explains. Measures recently taken to try to mitigate violence in sport include banning the sale and consumption of alcohol in sporting venues and prohibiting bringing in certain objects classified as potentially dangerous, such as flares, weapons, rigid poles or closed bottles, objects which have already caused more than one death in the sports arena in Spain. In football, unlike other sports, the rules of play and competition are opposed to each other, making fair play a difficult value to achieve if winning is always the priority. González-Oya (2010) analysed 28 match reports regarded as contentious from the Pontevedra Delegation of the Referees' Technical Committee of the Galician Football Federation for the 2003-2004 season, produced a database from these reports and proceeded to study it. The results confirm that many aggressions occur in regional football, that the match result does not usually play a decisive part in initiating them, that the aggressor is usually someone with a federation licence and that the main causes of violence detected are insults, aggressive acts, pitch invasions, throwing objects and damage to vehicles.

All the factors involved in the development of a more aggressive type of football eventually affect the heart of this sport, that is, youth football, where the players of tomorrow are trained and nurtured. For this reason, it is important to establish the real state of this youth or formative football, which will determine the psychological and social conditions in which players reach amateur football.

In studying aggression in football, Sáenz, Gimeno, Gutiérrez, and Elejalde (2012) take the view that anyone who does not seek to put an end to these phenomena does not value human dignity. Their study focuses on football at a formative age, more specifically in a cadete (under-16) category of football in Vitoria, over several seasons, with the primary objectives of acquiring knowledge of the incidence of sporting and unsporting attitudes and behaviour, as perceived by referees and coaches, and, on the basis of that knowledge, designing and implementing a programme of a preventive nature among the coaches of teams that do not behave in a sporting manner. The most significant result of their research is that in youth football there are many aggressive acts, which can be detected and dealt with, and they propose new 
lines of research to move forward in the direction already marked out.

The constant occurrence of antisocial and aggressive behaviour every weekend on the football field, behaviour outside the theoretical dictates of sporting practice, is the justification cited by Gutiérrez (2015) for initiating a study of aggression in football teams, emphasising the seriousness of this situation and how it will affect young players in the future. Like other studies (Abrahams, 2010; Pelegrín, 2002), it underlines the need to identify high-risk teams and act on them to combat the problem of aggression, and proposes implementing an action programme which it develops, the "Let's Play Fair in Youth Sport" Programme (Programa Juguemos Limpio en el Deporte de Base), applied in Aragon and the Basque Country, whose objectives are to prevent violence and foster sportsmanship in youth football categories. This study presents a design for a tool to assess sportsmanship, used to identify high-risk teams, to which a protocol is applied, seeking to improve their behaviour. The tool, known as the Register for Assessing Sportsmanship and Identifying Unsporting Events in Football (Registro de Evaluación de la Deportividad e Identificación de Sucesos Antideportivos en el Fútbol) (EDISAF), was implemented in all categories of football at autonomous community level, using the referee as the person who should complete this register for each match, always on a voluntary basis and without affecting the normal course of the competition. The results showed that greater problems with aggression arose in adolescent age groups; most of the high-risk teams were in the infantil (under-14), cadete (under-16) and juvenil (under-19) categories. Another factor which proved very significant was the match result; in matches with a larger difference between the teams in the number of goals scored, there seemed to be fewer problems related to aggression. This analysis clearly shows the need to address this problem in adolescence, to try to achieve amateur football categories free of aggression and players with a high level of sportsmanship in the future. A very significant point was that in one category those concerned opted to have the register completed by both the referee and the coaches, and the two results coincided, evidence that the referee's opinion can be sufficient to identify the high-risk teams, although the researcher himself acknowledges that the analysis ought to be more extensive.

Once aggressive behaviour has been detected in a sportsperson or a team, it is essential to consider some kind of intervention to correct this problem. In relation to sportsmanship and fair play, the contributions of Lamoneda (2014) are of great interest. After presenting the problem of aggression in sport as something that has already been studied but not solved, and explaining its high incidence in the world of football, where cheating, aggressions and unsporting behaviour occur very frequently, the author goes on to describe a method for designing a programme to be implemented at alevin (under-12) level, verifying its effectiveness and trying to promote fair play. Working with a sample of rather more than a hundred footballers, he obtained the following main results: after more than two months of intervention, the players who followed the programme had improved significantly in terms of control, respect for the referee, concern for injured players, accepting mistakes and showing more courtesy to opposing players. However, the method proved unable to change behaviour with regard to effort and correcting situations unfair to an opponent. In his conclusions, the author considers that these results confirm that the programme can be successfully implemented in players at such early ages.

Gómez (2007) takes the view that violence in sport is not the same as violence in society; in other words, we cannot justify the presence of violence in sport on the grounds that we live in a violent society. Acceptance of this violence as normal behaviour by present-day society is the main obstacle we may encounter and perhaps the most striking issue.

Aggression in football intended to harm the referee needs to be addressed, and in order to be able to detect and measure it we have analysed a series of studies of a similar nature. Rodríguez (2010) focuses on the work 
of coaches, measures their conduct and refers to the importance of programmes aimed at improving certain behavioural aspects of schoolage sports coaches, such as the CET (Coaching Effectiveness Program) designed by Smith, Smoll, and Hunt (1977) in the 1970s, which sought to increase the presence of forms of conduct tending to support or reinforce prosocial behaviour. The author highlights the importance for young sportspersons of the well-known athletic triangle of family, coach and athlete, as it is the first major link between the sport and the person and will mark his or her future development. It is a matter of assessing the work of coaches with the CBAS (Coaching Behavior Assessment System) and implementing tools that enable them to improve the motivational climate, by measuring the results.

Along the same lines, there are studies (Cruz, 2001; Smoll \& Smith, 2006) that offer the coaches themselves advice on prior behavioural assessments. Sousa, Cruz, Torregrosa, Vilches \& Viladrich (2006) also discuss the important part played by the sporting environment in the development of sportspeople at early ages, highlighting the athletic triangle. Basing their arguments on the opinions of experts in sport psychology, they prioritise letting young sportspeople enjoy themselves and acquire skills or techniques pertaining to their sport over achieving competitive results, trying to ensure that adults do not spoil this process. The coach is identified as the crucial component in this mechanism, since he or she is the one who spends most hours with young people in their sports training, and two approaches to guiding them are distinguished: the positive approach, in which the aim is to highlight what they do well and makes them feel good, and the negative, which seeks to eliminate errors and punish faults.

In their study Sousa et al. (2006) obviously urge coaches to concentrate more on the positive approach, especially when they are training children and teenagers, and for assessing coaches' behaviour they again use the CBAS, which identifies reactive and spontaneous behaviours of various kinds that each coach specifically employs. Reactive behaviours are reinforcement or non-reinforcement of desirable conduct, encouragement when errors occur, technical instruction when errors occur, punishment, punitive technical instruction and ignoring errors after they are committed and maintaining control after disruptive behaviour. Spontaneous behaviours include general technical instruction, general encouragement, organisation and communication in general. This assessment instrument has been used very successfully in various sports, and the idea is to observe coaches to detect their habitual behaviours and try to improve them in the interests of better training for young sportspeople. The conclusion drawn from this study, conducted on a series of coaches, is that fostering the positive approach in coaches encourages training, enhances a positive perception of the coach and the sportsperson's own self-esteem, and reduces drop-out rates in child and youth sports.

However, aggressive conduct is not the only issue; it is also important to highlight and assess the motivational perspective from which the various agents in the world of football approach matches, bearing in mind the consequences of such behaviour. Rodríguez-Peláez et al.(2015) demonstrate the importance of CBAS, as an instrument which helps to measure and assess communication and the motivational climate that a coach transmits to his or her trainees. This study was applied to a single coach through four different observers. The CBAS results showed a level of agreement of more than $90 \%$ in the six observations to which the coach was subjected, making it quite clear that this instrument achieves its objectives very satisfactorily. The authors used a version of the CBAS proposed by Smith, Smoll and Hunt (1977) adapted to concentrate on the motivational area, giving it higher priority, or studying more items related to maintaining control after certain behaviour or in the event of spontaneous conduct associated with the match or training session. The ultimate objective or line of further work mentioned as a continuation of this study is to create personalised help programmes for coaches to improve the motivational climate with their trainees. 
The bonds that coaches form with the sportspeople they train, especially at early ages, are largely responsible for the development of those trainees in personal and sporting terms. Cruz, Torregrosa, Sousa, Mora, and Viladrich (2010) show us the importance of the coach for very young sportspeople, in relation to the part played by the motivational factor in developing children, not only from the sports point of view but also as people. They therefore focus on giving those who coach these young sportspeople personalised advice for improving their communication skills and creating a better motivational climate. Quite rightly, they severely criticise the fact that most trainers perform their duties voluntarily and without training. They point out the importance of studying coaches, both in training sessions and in matches, to assess their leadership and how their behaviour influences their young trainees, changing the performance, motivation, attitudes and actions of each of them. The importance of positive reinforcement and emphasising team values are other issues that should be guiding principles in coaches of these sports.

What the various intervention programmes have in common, is the need to individualise the psychological advice given to each coach, and this gives rise to a range of progammes, such as the pioneering one by Cantón and León (2005) or PAPE, the Personalised Advice Programme for Coaches (Programa de Asesoramiento Personalizado a Entrenadores) (Sousa et al., 2006), developed at the Universidad Autónoma de Barcelona, which aims to teach coaches which types of behaviour they should maintain and which they should reduce or eliminate from their behavioural repertoire. These studies show the effects of the various programmes on coaches of young sportspeople, in both football and basketball. For example, PAPE was applied to four cadete (under-16) football coaches and five basketball coaches of age-groups from infantil (under-14) to juvenil (under-18). The coaches were given an initial interview, and for each football coach eight matches were filmed and analysed by three observers fully trained for the purpose, with a level of agreement that was always above $90 \%$. In the case of basketball, for each coach two matches and two training sessions were filmed and analysed, and were assessed by an observer. A second phase consisted of the intervention with the coaches, showing them a DVD of the film taken of them so that they could see the positive aspects, those that needed to be improved and those that should be eliminated from their practice. Finally, the results were observed by filming more matches with each coach after this second phase, and the outcome, as was to be expected, was very positive in almost all cases, only proving unsuccessful with one of the football coaches. The point is that each coach, working with the team of psychologists, identifies which behaviours should be changed and which objectives they intend to achieve, and this personalisation is one of the strengths of these programmes.

Developing prevention and intervention programmes is important, not only because of the seriousness of these types of behaviour but also because of their prevalence, as demonstrated by some data on violence in amateur football and how it has progressed from the 2003-2004 to the 2015-2016 seasons. It is also important to have data analysis procedures that enable us to obtain clear and reliable information in order to set objectives and define interventions. For this purpose, the methodology used in this study is based on loglinear models, analysing a significant number and type of data to help to respond to these issues.

\section{Some data on violence in amateur football}

The annual reports presented by the State Comission against Violence, Racism, Xenophobia and Intolerance in Sport (Comisión Estatal contra la Violencia, el Racismo, la Xenofobia y la Intolerancia en el Deporte), under the authority of the Higher Sports Council (Consejo Superior de Deportes), show us the data for the incidence of violence in amateur sport (Table 1). 
Table 1

Violent incidents in amateur sport

\begin{tabular}{crrr}
\hline Season & Incidents & $\begin{array}{c}\text { Incidents } \\
\text { in football }\end{array}$ & \% \\
\hline $2003-2004$ & 327 & & \\
$2004-2005$ & 451 & 441 & 97.78 \\
$2005-2006$ & 446 & 422 & 94.62 \\
$2006-2007$ & 370 & 348 & 94.05 \\
$2007-2008$ & 309 & 296 & 95.79 \\
$2008-2009$ & 264 & 256 & 96.97 \\
$2009-2010$ & 283 & 271 & 95.76 \\
$2010-2011$ & 245 & 229 & 93.47 \\
$2011-2012$ & 233 & 223 & 95.71 \\
$2012-2013$ & 179 & 173 & 96.65 \\
$2013-2014$ & 202 & 194 & 96.04 \\
$2014-2015$ & 203 & 194 & 95.57 \\
$2015-2016$ & 232 & 218 & 93.97 \\
\hline
\end{tabular}

The enormous difference between the number of incidents in football and in other sports is clear from these data; as in professional sport, it accounts for the vast majority of cases. According to these figures, between $93 \%$ and $98 \%$ of violent incidents in amateur sport are recorded in football matches.

The predominance of football in the recorded presence of violent events is such that out of every 25 violent incidents that took place in sport in these thirteen seasons, 24 occurred in football matches. In the 2015-2016 season, according to data from the Higher Sports Council, there were a total of 942674 football federation licences in Spain, representing $26.69 \%$ of the total of 3586 133 licences for all sports federations, although it is true that in team sports, football accounts for nearly $60 \%$ of federation licences. The figures are similar in previous seasons.

Another very striking point is the surprising reduction in violent incidents, which have decreased by as much as $50 \%$ over the last decade. The number seems to have stabilised at around 200 cases per year, a marked improvement from nearly 400 cases in the first couple of seasons.

These reports contain further information, such as that included in Table 2, which shows the incidence of this violence towards referees in various categories. The table confirms that referees are the main victims of violent incidents in amateur sport, in that between approximately $40 \%$ and $50 \%$ of cases affect them.

Table 2

Incidence of violence towards referees

\begin{tabular}{crrr}
\hline Season & Total & Referees & \multicolumn{1}{c}{$\%$} \\
\hline $2003-2004$ & 327 & 191 & 58.41 \\
$2004-2005$ & 451 & 215 & 47.67 \\
$2005-2006$ & 446 & 214 & 47.98 \\
$2006-2007$ & 370 & 180 & 48.65 \\
$2007-2008$ & 309 & 147 & 47.57 \\
$2008-2009$ & 264 & 123 & 46.59 \\
$2009-2010$ & 283 & 135 & 47.7 \\
$2010-2011$ & 245 & 109 & 44.49 \\
$2011-2012$ & 233 & 96 & 41.2 \\
$2012-2013$ & 179 & 74 & 41.34 \\
$2013-2014$ & 202 & 77 & 38.12 \\
$2014-2015$ & 203 & 78 & 38.42 \\
$2015-2016$ & 232 & 115 & 49.57 \\
\hline
\end{tabular}

On the other hand, the number of violent incidents in amateur football involving intervention by the forces of law and order seems to have stabilised at around a hundred cases per year. As regards the analysis by category, just over $10 \%$ of these interventions in violent incidents in football occur at national level (2nd Division $\mathrm{B}$ and 3rd Division), around $20 \%$ in youth football and nearly $70 \%$ in regional football; the percentage in women's football is less than $1 \%$ (Figure 1). 
Figure 1

Progress of incidents in football

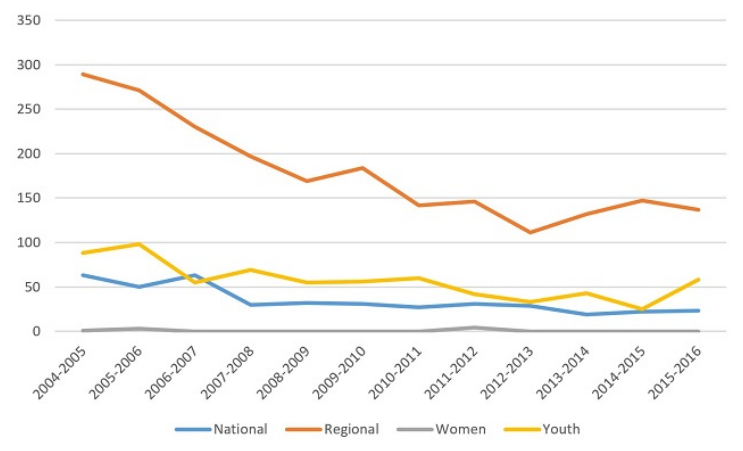

The decrease in cases, amounting to nearly $50 \%$ in all categories, can be clearly seen and seems to have stabilised for approximately the last 3 or 4 seasons.

If we focus on youth football, most incidents occur in the higher age categories (infantil [under-14], cadete [under-16] and juvenil [under-19]), sometimes with percentages close to 95\% of the total, as shown in Figure 2.

\section{Figure 2}

Incidents in youth football by category

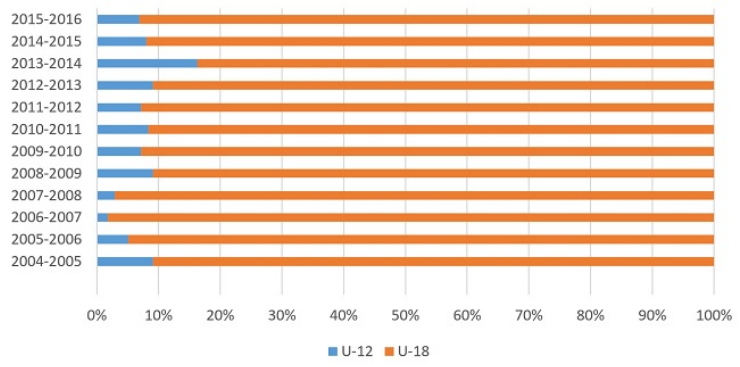

\section{Log linear models}

As we indicated in the introduction, our main objective is to study the prevalence of, and the possible relationships between, the various types of aggressive behaviour shown by players, coaches and spectators in football matches. Since there are three variables to be studied (aggression towards the referee by players, coaches and spectators), we can opt to study their relationships two by two using contingency tables or to study all three simultaneously. The second option seems the more appropriate, and for this purpose we have used a loglinear model.

The number of observations, $n_{i j}$, in a generic cell of a contingency table $I \times J$, under the hypothesis of independence or non-association between the categorical variables, $X$ and $Y$, which give rise to it, is given by $n_{i j}=n \times \pi_{i .} \times \pi_{. j}$, where $n$ is the total number of observations, $\pi_{i}$. is the proportion of observations in row $i$, and.$j$ is the proportion of observations in column $j$. If we take logarithms in the foregoing expression and make a minor change of notation, we obtain

$$
\log \mu_{i j}=\lambda+\lambda_{i}^{X}+\lambda_{j}^{Y}
$$

which represents a loglinear model of independence, in that only the row effect, $\lambda_{i}{ }^{x}$, and the column effect, $\lambda_{j}{ }^{X}$, are added to the main effect, $\lambda$, to obtain $\log \mu_{i j}$.

A loglinear model for a two-dimensional contingency table is simply a general linear model (GLM) that considers the number of observations in each of the $I \times J$ cells as independent observations from a Poisson distribution. This type of model, as can be seen from (1), does not distinguish between the response variable and explanatory variables, because it treats them both together when modelling $\mu_{i j}$, which is the result of combining their various categories. If we included the interaction between the two variables in (1) we would obtain

$$
\log \mu_{i j}=\lambda+\lambda_{i}^{X}+\lambda_{j}^{Y}+\lambda_{i j}^{X Y}
$$

the saturated model which perfectly describes any value $\mu_{i j}>0$.

In a two-dimensional table there are no situations of interest intermediate between independence and interaction between the variables, but if the table has more dimensions, particularly three as in our case, intermediate models are possible and of interest. For three categorical variables $X, Y$ and $Z$, the independence between them would be represented by the model 


$$
\log \mu_{i j}=\lambda+\lambda_{i}^{X}+\lambda_{j}^{Y}+\lambda_{k}^{Z}
$$

and the corresponding saturated model by

$\log \mu_{i j}=\lambda+\lambda_{i}^{X}+\lambda_{j}^{Y}+\lambda_{k}^{Z}+\lambda_{i j}^{X Y}+\lambda_{i k}^{X Z}+\lambda_{j k}^{Y Z}+\lambda_{i j k}^{X Y Z}$

Between models (3) and (4) we can find models that describe various types of interaction. For example, the model

$$
\log \mu_{i j}=\lambda+\lambda_{i}^{X}+\lambda_{j}^{Y}+\lambda_{k}^{Z}+\lambda_{i j}^{X Y}+\lambda_{i k}^{X Z}
$$

represents conditional independence of $X$ and $Y$, given $Z$, a weaker condition than unconditional independence. The theoretical details of this type of model can be consulted in Agresti (2006) and Faraway (2016).

\section{Data}

In order to be able to detect these aggressive behaviours towards the referee in football we propose assessing the associated attitudes during matches. To do so, we created an ad-hoc record sheet on which aggressive forms of behaviour are collected and grouped according to various degrees on a scale. This record sheet is reproduced in the Appendix. It separates the agents who participate in a football match, in addition to the referee, into the following categories:

Players: those who are on the field of play or on the bench and are recorded in the match report.

Coaches: all managerial personnel registered with the Federation who are on the bench.

Spectators: all those who do not belong to one of the two previous categories.

The referee's decisions are divided into three types:

Correct decision: when the referee is considered to have made the right decision.

"Grey-area" decision: when there is some doubt about a decision, whether of interpretation or for some other reason. Most decisions during a match are like this, and are so called because they are not black or white.
Error: when the referee is considered to have made a wrong decision.

The intensity of the reactions of the different agents to each of these situations was assessed according to the detailed explanation at the end of the record sheet. The highest level this intensity reached during the match was recorded on the sheet; an expert was responsible for assessing it. In addition, at the end of the match the referee was asked about the aggressiveness he had felt from each group, after showing him the scale.

Once the record sheet had been drawn up, it was validated by three experts who attended two football matches, one 8-a-side and another 11-a-side, distributed in various parts of the facilities where they could clearly see and hear the main stand and the technical area, and they completed the corresponding sheets, which were subsequently compared. Since there were more than two experts, Fleiss's $\kappa$ was used, and its values were 0.93 and 0.90 respectively.

Once the record sheet was validated, we collected the data from a further 119 matches in different categories, in the city of Valencia and nearby municipalities, during the 2016/17 season. The sample of matches was obtained using cluster sampling.

\section{Results and discussion}

The data obtained from the 119 record sheets provide two views, that of the observer who filled in the sheet and that of the referee. For the former, we analysed the maximum aggressiveness (MA) towards the referee detected in the spectators, coaches and players, regardless of whether it was a correct decision, an error or a "grey-area" decision. For the latter, we analysed the opinion of the referee $(O R)$ on the aggressiveness he observed towards him from the spectators, coaches and players.

The three variables involved in both analyses are categorical, with the same three categories: absence (aggressiveness level 0), protests (agressiveness levels 1 and 2) and aggression (aggressiveness levels 3, 4 and 5). The 
result of cross-tabulating the three variables for MA and OR is shown in Tables 3 and 4.

\section{Table 4}

Table of the aggressiveness observed by the referee $(\mathrm{OR})$

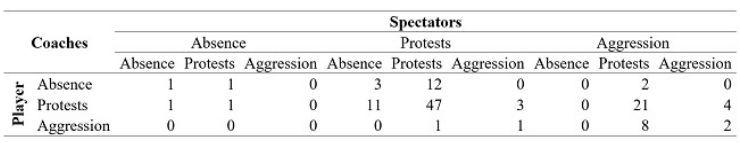

Table 4

Table of the Aggressiveness Observed by the Referee $(\mathrm{OR})$

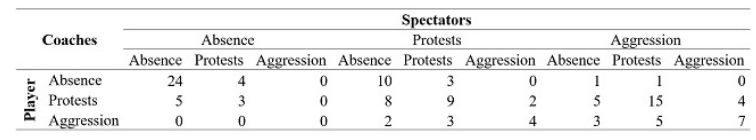

In both tables we can see a large number of empty cells: 11 out of 27 for MA and 7 out of 27 for OR. This represents a limitation when it comes to applying the loglinear model. We therefore construct new variables by collapsing the three categories into two: no = absence of protest or aggression, yes $=$ some protest or aggression. The result of cross-tabulating these new variables is shown in Table 5.

\section{Table 5}

Tables Resulting from Recoding the Categories of Tables 3 and 4

\begin{tabular}{cccccccc}
\hline \multicolumn{4}{c}{ MA } \\
\hline \multicolumn{1}{c}{ Spectators } & Players & Coaches & Frequency & Spectators & Players & Coaches & Frequency \\
\hline no & no & no & 1 & no & no & no & 24 \\
no & yes & no & 1 & no & yes & no & 5 \\
no & no & yes & 1 & no & no & yes & 4 \\
no & yes & yes & 1 & no & yes & yes & 3 \\
yes & no & no & 3 & yes & no & no & 11 \\
yes & yes & no & 11 & yes & yes & no & 18 \\
yes & no & yes & 14 & yes & no & yes & 4 \\
yes & yes & yes & 87 & yes & yes & yes & 50 \\
\hline
\end{tabular}

Results for $\mathrm{MA}$

We begin the analysis with the simplest model, that which only takes account of principal effects, which amounts to saying that there is independence between the aggression of the three actors involved: players, coaches and spectators.

The adjustment of the loglinear model is performed with the $\mathrm{glm}$ function in R software (2017) using the link log so that the number of observations in each cell is treated as a Poisson variable. Table 6 shows the result of the adjustment.

Table 6

Result of the Adjustment of the Loglinear Model for MA

\begin{tabular}{lrr}
\hline \multicolumn{1}{c}{ MA } & Coefficient & \multicolumn{1}{c}{ SE } \\
\hline Constant & $-2.454^{*}$ & 0.59 \\
Players.yes & $1.66^{*}$ & 0.25 \\
Coaches.yes & $1.862^{*}$ & 0.268 \\
Spectators.yes & $3.358^{*}$ & 0.508 \\
\hline \multicolumn{4}{c}{$* p<0.001$}
\end{tabular}

Let us recall that the categorical variables are introduced into the model through dummy variables, and the number of dummy variables is the number of categories minus one. Since in our case they are dichotomous variables, only one category appears in the model, specifically the one corresponding to the value yes. The residual deviance of the model is 6.3453 , a value close to 4 , which is the number of degrees of freedom in the model, and this suggests a good fit, as is corroborated by the corresponding $\chi^{2}$ test with a p-value $=0.1748$. We can therefore take the model as sound and accept that there is independence between the three factors players, coaches and spectators. In other words, the aggressive acts of one of these groups do not seem to influence the other two. Table 7 shows the observed values and those estimated using the model.

Table 7

Observed and Adjusted Frequencies by the Loglinear Model for MA

\begin{tabular}{cccrr}
\hline & MA & \multicolumn{3}{c}{ Frequency } \\
\hline Spectators & Players & Coaches & Observed & Adjusted \\
\hline No & No & No & 1 & 0.1 \\
No & Yes & No & 1 & 0.4 \\
No & No & Yes & 1 & 0.6 \\
No & Yes & Yes & 1 & 2.8 \\
Yes & No & No & 3 & 2.5 \\
Yes & Yes & No & 11 & 13 \\
Yes & No & Yes & 14 & 15.9 \\
Yes & Yes & Yes & 87 & 83.7 \\
\hline
\end{tabular}




\section{Results for OR}

Again, we adjusted the simplest model, which assumes independence between the three variables involved. Here the fit is not good, since the value of the residual variance is 74.472 with

4 degrees of freedom. The corresponding $\chi^{2}$ has an associated $\mathrm{p}$-value $=2.5769 \mathrm{E}-15$.

A less parsimonious model that introduces interactions between the variables is required. An easy model to interpret is the homogeneous association model, which assumes that each variable is associated with another, but that this association is the same for either of the two categories of the third variable. Its expression is

$$
\log \mu_{i j}=\lambda+\lambda_{i}^{X}+\lambda_{j}^{Y}+\lambda_{k}^{Z}+\lambda_{i j}^{X Y}+\lambda_{i k}^{X Z}+\lambda_{j k}^{Y Z}
$$

\section{Table 8}

Result of Adjusting the Homogeneous Loglinear Model for OR

\begin{tabular}{|c|c|c|}
\hline OR & Coefficient & $S E$ \\
\hline Constant & $3.203 *$ & 0.198 \\
\hline Players.yes & $-1.724 *$ & 0.458 \\
\hline Coaches.yes & $-1.982 *$ & 0.493 \\
\hline Spectators.yes & $-0.862 *$ & 0.348 \\
\hline Players.yes $\times$ Coaches.yes & $1.788^{*}$ & 0.514 \\
\hline Players.yes $\times$ Spectators.yes & $2.307 *$ & 0.525 \\
\hline Coaches.yes $\times$ Spectators.yes & $1.17 *$ & 0.553 \\
\hline
\end{tabular}

The residual deviance of the model has a value of 0.4593 with 1 degree of freedom, and the corresponding $\chi^{2}$ test has a $\mathrm{p}$-value $=$ 0.4980. Table 9, with the observed and adjusted frequencies, corroborates the goodness of fit.
Table 9

Observed and Adjusted Frequencies by the

Loglinear Model for OR

\begin{tabular}{cccrr}
\hline & OR & \multicolumn{2}{c}{ Frequency } \\
\hline Spectators & Players & Coaches & Observed & Adjusted \\
\hline No & No & No & 24 & 24.6 \\
No & Yes & No & 5 & 4.4 \\
No & No & Yes & 4 & 3.4 \\
No & Yes & Yes & 3 & 3.6 \\
Yes & No & No & 11 & 10.4 \\
Yes & Yes & No & 18 & 18.6 \\
Yes & No & Yes & 4 & 4.6 \\
Yes & Yes & Yes & 50 & 49.4 \\
\hline
\end{tabular}

Interpretation of the homogeneous model for $\mathrm{OR}$

The homogeneous model assumes that the interaction between two variables is independent of the value taken by the third. To interpret this type of model, it is important to remember that the $\exp (\mathrm{coef})$ of the interactions represents an odds ratio. If we recall that the adjustment takes the value no as a reference category, we are speaking of

$$
\exp \left(\operatorname{coe} f_{X, y e s \times Y, y e s}\right)=\frac{P(X=y \theta s) / p(X=n o)}{P(Y=y \theta s) / P(Y=n o)} .
$$

For example, for that of the interaction players.yes $\times$ coaches.yes, the value of its coefficient is 1.7880 and $\exp (1.7880)=5.9775$. This means that if, in the referee's opinion, there was aggression towards him from the players (yes), the probability that he considers that there was also aggression from the coaches is approximately 6 times greater than if he had considered that the players did not show aggression (no), regardless of his opinion of the aggressiveness of the spectators.

A similar explanation applies to the other two coefficients:

$$
\begin{aligned}
& \exp \left(\text { coef }_{\text {players.yes } \times \text { spectators.yes }}\right)=10.0477 \\
& \exp \left(\text { coef } f_{\text {coaches.yes } \times \text { spectators.yes }}\right)=3.2244 .
\end{aligned}
$$


Finally, it is interesting to calculate the $95 \%$ confidence intervals for these odds ratios, and as was to be expected none of them contains unity (Table 10).

\section{Table 10}

Confidence Intervals for the Odds Ratios of the Interactions for $\mathrm{OR}$

\begin{tabular}{lr}
\hline \multicolumn{1}{c}{ Interactions for OR } & \multicolumn{1}{c}{ CI } \\
\hline Players.yes $\times$ Coaches.yes & $2.236-17.186$ \\
Players.yes $\times$ Spectators.yes & $3.71-29.572$ \\
Coaches.yes $\times$ Spectators.yes & $1.094-9.875$ \\
\hline Odds Ratios & $97.5 \%$ \\
\hline
\end{tabular}

\section{Conclusion}

This study challenges the idea that aggressive behaviours of players, coaches and spectators towards the referee are related, since the result we obtained from the data in the record sheets of the matches analysed was that their presence is independent, whereas in the referee's view this is not so, which coincides with the traditional opinion in the football world.

The aggressive acts towards the referee that are detected in a match on the part of players, coaches and spectators are independent; that is, the presence or absence of any of them is not significantly or causally related to the presence or absence of the others. Our understanding, therefore, is that the three agents studied, players, coaches and spectators, act independently as regards their aggressive behaviour towards the referee, despite what might be expected in view of the classic determinants of the football world, such as the atmosphere and mood of the match and the pressures exerted by constant protests.

This represents a departure from the traditional idea that spectators have infected players or coaches with aggression, or any other relationship, such as the idea, for example, that an aggressive attitude on the part of coaches gives rise to aggressive attitudes in players or spectators (referring in each case to attitudes towards the referee).
However, the opinion of referees on the forms of aggression they suffer from these three groups during a match is that they are related, directly in all three cases, and that the relationship between players and coaches is the strongest. Thus, when the match has finished, referees still have this idea, which is traditional within the football world, giving them the impression that the aggressive behaviours of the different agents are indeed related, such that the presence of one of them increases the probability that either of the others will be present.

The same is true in the case of absence of these aggressive behaviours, which leads us to conclude that if the referee feels that the match is calm and there is no aggression, he or she will tend not to detect it in any of the three agents, and if referees become aware of aggressive behaviour during the match they will tend to be aware of it from all three of the agents involved. The total presence of such behaviours or their total absence are the predominant trends as regards the referee's assessment at the end of the match.

As future lines of research it would be interesting to expand the number of matches and areas, continuing to sample all categories of football, so as to compare aggressive behaviours in each region and between regions. We would obtain a register with rates of aggression towards the referee in football matches, which should lead to the creation and implementation of measures to reduce these levels and try to prevent things reaching the point of physical assault, the last degree on the scale of aggressiveness that arises.

Regarding the design of prevention programmes, creating measuring instruments with the aid of the observed variables to establish levels of risk in teams in any of their three observed agents would be a way of starting to work with those teams. On the other hand, in designing intervention programmes account will be taken of which one or more of the three agents involved need this intervention. Comparing those same measurements in postintervention matches with the results already obtained will help us to ascertain and assess the success of such programmes. 


\section{References}

Abrahams, M. (2010). Anger management in sport: Understanding and controlling violence in athletes. Champaign, IL: Human Kinetics.

Agresti, A. (2006). Categorical data analysis (2nd. ed.). Hoboken, NJ: Wiley-Interscience.

Cantón, E., \& León, E. (2005). La resolución de conflictos en la práctica deportiva escolar. Cuadernos de Psicología del Deporte, 5(1-2), 159-171. Retrieved from https://revistas.u m.es/cpd/article/view/93471

Cruz-Feliu, J. (2001). Factores motivacionales en el deporte infantil y asesoramiento psicológico a entrenadores y padres. In J. Cruz Feliu (Ed.), Psicología del Deporte (pp. 147-176). Madrid: Síntesis.

Cruz, J., Torregrosa, M., Sousa, C., Mora, A., \& Viladrich, C. (2010). Efectos conductuales de programas personalizados de asesoramiento a entrenadores en estilo de comunicación y clima motivacional. Revista de Psicología del Deporte, 20(1), 179-195. Retrieved from https://www.rpd-o nline.com/article/viewFile/850/707

Faraway, J. J. (2016). Extending the linear model with $R$ : Generalized linear, mixed effects and nonparametric regression models (2nd. ed.). Boca Raton, FL: Chapman \& Hall/CRC.

Gómez, Á. (2007). La violencia en el deporte. Un análisis desde la Psicología Social. Revista de Psicología Social, 22 (1), 63-87. https://doi.or $\mathrm{g} / 10.1174 / 021347407779697539$

González-Oya, J. L. (2010). Aproximación a la violencia en el fútbol y en el arbitraje. Revista Iberoamericana de Psicología del Ejercicio y el Deporte, 1(2), 29-44. Retrieved from https://accedacris.ulpgc.es/bitstream/ 10553/7763/1/0537108_20062_0002.pdf

Gutiérrez, H. (2015). Evaluación de la deportividad en equipos de fútbol y prevención del comportamiento antideportivo en equipos de riesgo (Doctoral dissertation). Universidad de Zaragoza, España.

Kavussanu, M. (2006). Motivational predictors of prosocial and antisocial behaviour in football. Journal of Sports Sciences, 24(6),
575-588. https://doi.org/10.1080/02640410 500190825

Lamoneda Prieto, J. (2014). Intervención para la mejora de las orientaciones hacia la deportividad en futbolistas alevines (Doctoral dissertation). Universidad de Extremadura, Badajoz.

Pelegrín Muñoz, A. (2002). Conducta agresiva y deporte. Cuadernos de Psicología del Deporte, 2(1), 39-56. Retrieved from https://revistas .um.es/cpd/article/view/105021/99951

Rodríguez-Martínez, M. P. (2010). Diseño, aplicación y evaluación de un programa de intervención psicológica en equipos juveniles de fútbol (Doctoral dissertation). Universitat Autònoma de Barcelona.

Rodríguez-Peláez, D., Garrido, P., Conde, C., \& Almagro, B. J. (2015). Adaptación y validación de la CBAS para la observación de climas motivacionales. Cuadernos de Psicología del Deporte, 15(3), 253-260. Retrieved from https://revistas.um.es/cpd/a rticle/view/244721/185511

Sáenz, A., Gimeno, F., Gutiérrez, H., \& Elejalde, A. (2012). Prevención de la agresividad y la violencia en el deporte en edad escolar: un estudio de revisión. Cuadernos de Psicología del Deporte, 12(2), 57-72. https://doi.org/10 .4321/S1578-84232012000200007

Shields, D. L., Light Bredemeier, B., LaVoi, N. M., \& Power, F. (2005). The sport behavior of youth, parents and coaches: The good, the bad and the ugly. Journal of Research in Character Education, 3(1), 43-59. Retrieved from http://www.infoagepub.com/assets/file s/sports_JRCE_3-1_txt.pdf

Smith, R. E., Smoll, F. L. ., \& Hunt, E. (1977). A system for the behavioral assessment of athletic coaches. Research Quarterly, 48(2), 401-407. https://doi.org/10.1080/10671315 .1977 .10615438

Smoll, F. L., \& Smith, R. E. (2006). Enhancing coach-athlete relationships: Cognitivebehavioral principles and procedures. In J. Dosil (Ed.), The sport psychologist's handbook: A guide for sport-specific performance enhancement (pp. 19-37). Chichester, UK: John Wiley \& Sons. 
Sousa, C., Cruz, J. Torregrosa, M., Vilches, D., \& Viladrich, C. (2006). Evaluación conductual y programa de asesoramiento personalizado a entrenadores (PAPE) de deportistas. Revista de Psicología del Deporte, $15,263-278$.

\section{Appendix A}

\section{Record sheet}

\section{Explanation and instructions for the record sheet}

Questions 1, 2 and 3

$0=$ Absence of aggression.

$1=$ Criticisms and negative comments to the referee that stop short of insults or disrespect.

2 = Showing disrespect for the referee and making rude gestures but stopping short of insults.

3 = Obscene, vulgar or offensive comments and gestures to the referee.

$4=$ Attempted assaults, spitting and very intimidating attitudes towards the referre.

$5=$ Physical assault of the referee.

Questions 4, 5 and 6

Enter the number of behaviours that should be included in the match report for each group or that have occurred during the match. In addition, in the case of questions 4 and 5 the notes at the end of the sheet should indicate the nature of these behaviours. The number should be entered normally up to five times, and beyond that point 5 should be marked even if more incidents are recorded in the notes at the end.

\section{Question 7}

The highest level reached in the first three questions for each group.

\section{Question 8}

Yes, if it was sold, or No otherwise, and whether the referee included it in the match report.

\section{Question 9}

To be completed by the referee, at the end of the match, expressing his or her opinion, according to the criteria established for questions 1,2 and 3.

\section{Question 10}

To be completed after checking the match report, adding comments in the final section if necessary.

\section{Other noteworthy incidents}

Describe all the events enumerated in questions 4 and 5 , as well as any other point worthy of attention.

\section{Notes}

* Research article. 